\title{
MAST CELLS IN LUNG OF RAT
}

\author{
I. Ivanova* \\ Department of Anatomy, Faculty of Medicine, Trakia University, Stara Zagora, Bulgaria
}

\begin{abstract}
This paper is a short review of scientific literature on lung mast cells in norm and pathology that shows the current state of this problem. Particular attention is paid to the quantity, location and arrangement of the mast cells. The mast cells are a part of immune system whom origin are myeloid stem cells. They are a kind of white blood cells. Many authors from the 19th century to the present day have traced and described the role of mast cells in the human body, their structure and changes depending on the functional state of the organism.

Paul Ehrlich is the first author that described in his doctoral thesis the mast cells as effectors of allergy particularly in the beginning of reaction and in acute phase of the process. Research has continued through out the 20th century and researchers' efforts are primarily focused on clarifying the structure and function of mast cells and identifying their role in pathological responses in the human body.

Mast cells are found in all organs, but they predominate in peripheral blood, spleen and bone marrow. There are cells in the rat skin that live for about 12 weeks, and more recent studies have found that proliferation of mature mast cells is caused by various factors.
\end{abstract}

Key words: mast cells, lung, proliferation, morphology

\section{INTRODUCTION}

The mast cells are a part of immune system whom origin are myeloid stem cells. They are a kind of white blood cells (1). Initially, their presence in the tissues was associated with an allergic reaction and the number of mast cells is up in response to infection by helminthes and protozoa, autoimmune and inflammatory disorders of the joints (2).

There are investigations of the role of mast cells for hypersensitivity (3). These authors describe the role of mast cells, basophils and eosinophils in this process.

There are some mast cells tumors that secrete products of degranulation. Some authors describe a mast cell activation syndrome (4).

\section{PURPOSE AND TASKS}

The aim of this study is to make a brief literary review of the morphological characteristics of the mast cells in relation with rat lung and its reaction in an emergency.

To accomplish this goal, we set out the following main tasks:

*Correspondence to: Ivelrna Gancheva Ivanova, Department of Anatomy, Faculty of Medicine 11 Armejska, Stara Zagora 6000, Bulgaria e-mail: ivcho_84@abv.bg
1. To review our available literature related to mast cell morphology.

2. To present contemporary articles those are related to lung mast cell research.

3. To establish the current state of lung-related studies of mast cells.

\section{LITERARY REVIEW}

Paul Ehrlich (5) is the first author that described in his doctoral thesis the mast cells as effectors of allergy particularly in the beginning of reaction and acute phase of the process. He and his followers studied the morphological features of mast cells and their physiological status in norm and pathology. Ehrlich describes mast cells as metachromatic cells containing granules that are functionally related to surrounding tissues.

Some authors $(6,7)$ described the histamine as functionally active mast cell mediator in rats. Other published the content of granules in mast cells (8). The synthesis of histamine is a process of histidine decarboxylation under the impact of enzyme histidine decarboxylase ( 9 , $10)$.

The similarity between mast cells and basophil granulocytes is supported by many authors (11, 12, 13). After experiments on cell cultures they 
demonstrate the truth of the role of interleukin 3 as a growth and differentiation factor for mouse mast cells.

There are investigations (14) of the hematopoietic origin of the mast cells in rodents. These authors implant bone marrow from domestic white mice $\left(\mathrm{C} 57 \mathrm{Bl} \mathrm{Bg}^{\mathrm{J}} / \mathrm{Bg}^{\mathrm{J}}\right.$ ) into wild mice (type C57Bl). Large granules of wild mice mast cells appear into the mast cells of recipient domestic mice. These authors reach a conclusion that mast cells derive from precursor cells of bone marrow and they are changed under the influence of wild mice marrow Jamur et al. (15) use a method of immunomagnetic isolation with two kinds of mast cell specific antibodies (mAb AA4 and $\mathrm{mAb}$ BGD6) and isolate a mast cell committed precursor $\mathrm{MCcp}\left(\mathrm{CD} 34^{+} \mathrm{CD} 13^{+} \mathrm{c}-\mathrm{Kit}^{+} \mathrm{Fc} \in \mathrm{RI}^{-}\right)$ from the bone marrow of adult mice.

The same team use mast cell specific monoclonal bodies for identification and isolation of rat bone marrow-derived mast cells (16).

In recent times, researchers' efforts have been directed towards revealing the molecular mechanisms of fat cell action (17) and the mechanisms of release and secretion pathways of mast cell mediators (18). These authors described two kinds of degranulation in human, rats and mouse. In PMD (piecemeal degranulation) process mediator is released in portions without membrane fusions. In AND (anaphylactic degranulation) process there is an explosive release of mediator after granule membrane fusion.

Ashmole and Bradding (19) investigate the importance of ion channels for the regulation of cell biology. They ascertain the fact that cation channels are activated by extracellular ATP and its concentration is presented around mast cells in inflamed tissues. P2X are ligandgated receptors and they conduct $\mathrm{Ca} 2+$ influx into mast cells. Different P2X receptors mast cells may be able to tailor their response to ATP in a concentration dependent manner.

After biochemistry investigation some authors described that except allergic reactions mast cells are involved in angiogenesis and immune tolerance, the cerebro-vascular barrier, and in the protection against many pathogenic factors (20). These authors described that mast cells use different mechanisms for recognization of pathogenic factors.

According Polyzoidis et al. (21) mast cells are located in various regions of the brain. These authors described numerous granules that secrete mediators like CRH (corticotropinreleasing hormone), SP (substance P), NT (neurotensin), VIP (vasoactive intestinal peptid), prostaglandins, leucotriens etc. chemokines and cytokines are described in mast cell secretion too.

Mast cells are present in lung of human and rat. They are located in two places. Fixed mast cells are found in epithelium of lung and free mastocytes are in the bronchial lumen (22). The mediators of these cells are in the base of some pulmonary diseases symptoms: smooth muscle constriction, mucus production, edema and cough.

Most of investigators described the state of mast cells in connection with pulmonary diseases (23) but they declare that mast cells play an important role in the lung in both health and disease. According these authors mast cells are important for immunity against bacterial infection and to initiate an appropriate program of inflammation.

New investigations in last years search a connection between mast cells in the lung as a culprit and respiratory disorders $(24,25)$. The same author suggests that in vitro mast cell models are a future possibilities in the investigations. He release his results of immunohistochemical identification of tissue mast cells and identification of tissue mast cells by flow cytometry.

\section{CONCLUSIONS}

A great part of the current knowledge on the mast cells has been gained by the culture of mouse BMMCs in vitro in the presence of growth factors. Some investigators agree that IL-3 favors the development of a mucosal mast cell phenotype in vitro (2) but they are critical for the development of murine BBMCs in vivo.

Two subtypes of mature mast cells have been described in rodents: mucosal mast cells (MMCs) and connective tissue mast cells (CTMCs) (27). In mouse, MMCs is described in the mucosal epithelium of the lung and gastrointestinal tract. The protease content of mouse mast cells is characterized by chymases mMCP-1 and mMCP-2 that are found to chondroitin sulfate chains of serglycin proteoglycans.

The literary review presents that the publications for mast cells are numerous but most of investigations for mast cells in lung are clinically. Theoretical observations are not too frequent. This is a reason for realization of this studying. 


\section{REFERENCES}

1. Prussin, C. and Metcalfe, D.D. IgE, mast cells, basophils, and eosinophils. J Allergy Clin Immunol. 111 (2 Suppl): 486-494, 2003.

2. Frieri, M. Mast Cell Activation Syndrome. (7th ed.). New York, NY: Elsevier, 2015.

3. Abbas, A., Lichtman, A., Pillai, S. Role of Mast Cells, Basophils and Eosinophils in Immediate Hypersensitivity. In: Cellular and Molecular Immunology (7th ed.). New York, NY: Elsevier, 2011.

4. Akin, C., Valent, P., Metcalfe D. Mast cell activation syndrome: Proposed diagnostic criteria. J. Allergy Clin. Immunol. 126 (6): 1099-104.e4,

2010. doi:10.1016/j.jaci.2010.08.035.

5. Ehrlich, P. Beiträge zur Theorie und Praxis der histologischen Färbung (Contribution to the theory and practice of histological dyes), Dissertation. Leipzig University, 1878.

6. Rocha E Silva, M. Concerning the mechanism of anaphylaxis and allergy. Brit Med J. 1(4762): 779-784. 1952.

7. Riley, J. and West G. The Occurrence of Histamine in Mast Cells. In: Histamine and Anti-Histaminics. pp. 116-135, 1966.

8. Barrnett, R., Hagen P.and Lee. F.L. Mastcell granules containing 5hydroxytryptamine, histamine and heparin, morphologically and biochemically distinct from mitochondria. Biochem. J. 69: 36, 1958.

9. Yamaguchi, K. Induction of histidine decarboxylase, the histamine-forming enzyme, in mice by interleukin- 12 . Toxicology, 156, 57-65, 2000.

10.Ohtsu, H. Histamine synthesis and lessons learned from histidine decarboxylase deficient mice. Adv exp med biol. 709: 2131, (2010).

11.Marieb, E. K. Hoehn. Human Anatomy and Physiology (6th ed.). San Francisco: Pearson Benjamin Cummings. p. 805, 2004.

12.Razin, E., Cordon-Cardo, C., Good, R.A. Growth of a pure population of mouse mast cells in vitro with conditioned medium derived from concanavalin A-stimulated splenocytes. Proc Natl Acad Sci USA. 78, 4: 2559-2561, 1981.

13.Razin, E., Ihle, J., Seldin, D., MenciaHuerta, J.M., Katz, H.R., LeBlanc, P.A., Hein A., Caulfield, J.P., Austen, K.F., Stevens, R.L. Interleukin 3: A differentiation and growth factor for the mouse mast cell that contains chondroitin sulfate E proteoglycan. J Immunol. 132 (3): 1479-86, 1984.
14.Dahlin, J. and Hallgren, J. Mast cell progenitors: Origin, development and migration to tissues. Mol Immunol. 63(1): 9-17, 2015.

15.Jamur, M., Grodzki, A., Moreno, A., Swaim, W., Siraganian, R., Oliver, C. Immunomagnetic isolation of rat bone marrow-derived and peritoneal mast cells. $J$ Histochem and Cytochem. 45(12): 17151722, 1997.

16.Jamur, M., Grodzki, A. Moren,o A., de Mello, L.,de F., Pastor, M.V., Berenstein, E.H., Siraganian, R.P., Oliver, C.Identification and isolation of rat bone marrow-derived mast cells using the mast cell-specific monoclonal antibody AA4. $J$ Histochem and Cytochem. 49(2): 2, 219228, 2001.

17.Lee, J., Veatch, S.L., Baird, B., Holowka, D. Molecular mechanisms of spontaneous and directed mast cell motility. J Leukoc. Biol. 92 (5): 1029-41, 2012.

18.Moon, T., Befus, A., Kulka, M. Mast cell mediators: their differential release and the secretory pathways involved. Front Immunol. 5: 569, 2014. doi: 10.3389/fimmu.2014.00569

19.Ashmole, I., Bradding, P. Ion channels regulating mast cell biology. Clin Exp Allergy. 43 (5): 491-502, 2013.

20.da Silva, E.Z., Jamur, M.C., Oliver, C. Mast cell function: a new vision of an old cell. $J$ Histochem Cytochem. 62 (10): 698-738, 2014.

21.Polyzoidis, S, Koletsa T, Panagiotidou S, Ashkan K, Theoharides TC (2015). Mast cells in meningiomas and brain inflammation. J Neuroinflammation. 12 (1): 170.

22. Wasserman, S.I. The human lung mast cell. Environ Health Perspect. 55: 259-69, 1984.

23. Moiseeva, E., P. Bradding Mast cells in lung inflammation. Adv Exp Med Biol. 716: 235-69, 2011.

24.Erjefält, $J$. Mast cells in human airways: the culprit? Eur Respir Rev. 23: 299-307, 2014.

25.Bradding, P., Walls, A., Holgate, S.. The role of the mast cell in the pathophysiology of asthma. J Allergy Clin Immunol. 117: 1277-1284, 2006.

26.Nakahata, T., Kobayashi, T., Ishiguro, A., Tsuji, K., Naganuma, K., Ando, O., Yagi, Y., Tadokoro, K., Akabane. T. Extensive proliferation of mature connective-tissue type mast cells in vitro. Nature 324: 65-67, 1986.

27.Enerbäck L, S. Kolset, M. Kusche, A. Hjerpe, U. Lindahl Glycosaminoglycans in rat mucosal mast cells. Biochem J. 227: 661-668, 1985. 
IVANOVA I. 